\title{
The Two-Stage Least Squares Regression of the Interplay between Education and Local Roads on Foreign Direct Investment in the Philippines
}

\author{
Ricardo Laurio DIZON*, Zita Ann Escabarte CRUZ**
}

Received: February 12, 2020 Revised: February 24, 2020 Accepted: March 6, 2020.

\begin{abstract}
This study aims to investigate the interplay between education and local roads on Foreign Direct Investment (FDI) in the Philippines, using economic growth as an instrument. The study used the quantitative research design applying both descriptive and inferential statistics. A combination of Two Stage Least Square Regression Model and three approaches in Panel Regression Model such as Pooled Least Square, Fixed Effect Model, and Random Effect Model were utilized in order to study the effects of education and local roads on foreign direct investment of the Philippines. Based on Fixed Effect regression results, higher education graduates and local road investments, as conditioned by economic growth, were significant factors in order to increase the foreign direct investment in the Philippines. Accordingly, a unit increase in higher education graduates, as conditioned by economic growth, leads to 8.758 unit increases in the foreign direct investment. While, a unit increased in local road investments, as conditioned by economic growth, leads to a 0.002 decrease in foreign direct investment. The regression results of the study suggest that the Foreign Direct Investment in the regions such as CAR, I, II, IV-B, V, VIII, IX, X, XI, XII, XIII, and ARMM are higher compared to Region IV-A.
\end{abstract}

Keywords: Foreign Direct Investment, Higher Education Graduates, Local Road Investments, Gross Regional Domestic Product, Two-Stage Least Squares

JEL Classification Code: G31, E62, E12, E22, E20.

\section{Introduction}

Foreign direct investment (FDI) is one of those financial flows that help the developing economies to overcome policy challenges to achieve economic development. It is considered as a main source of transfer of technology between countries and considered as a primary source of external finance. FDI enable to transfer funds from wealthier countries to countries with scarce amounts of capital and vital influencing the macro economy of a

*First Author and Corresponding Author. Associate Professor, Graduate School, Polytechnic University of the Philippines, Philippines [Postal Address: South 314, Institutional Planning Office, Polytechnic University of the Philippines, Anonas Street, Santa Mesa, Manila, 1016, Philippines] Tel: (+632) 53351787,

Email: rldizon@pup.edu.ph

**Budget and Management Specialist, Department of Budget and Management, Philippines. Email: zescabarte@dbm.gov.ph

(C) Copyright: The Author(s)

This is an Open Access article distributed under the terms of the Creative Commons Attribution Non-Commercial License (http://Creativecommons.org/licenses/by-nc/4.0/) which permits unrestricted noncommercial use, distribution, and reproduction in any medium, provided the original work is properly cited. country (Mohamed Mustafa, 2019). A country with vast inflow of FDI strengthens its connectivity to trade networks and strategizes to reduce or eliminate barriers to global FDI integration.

Many countries, including the Philippines, compete with each other in attracting FDI. To attract foreign investment inflow, it is essential to identify major determinants of the FDI. Macroeconomic variables such as economic growth rate, market size, infrastructure, political situation, government policies, and natural resources are considered factors that could influence the FDI flows (Woldemeskel, 2008). Policymakers in developing economies consistently crafting policies to attract FDI and offer incentive packages that would ensure that their country will be the host for many of these potential investments.

In the Philippines, the Investment Promotion Agencies offer various investment incentives to attract investors to place their capital in the country. The Philippines offers tax incentives such as income tax holiday, reduced tax rates on gross income earned, import duty exemptions, and accelerated depreciation allowance, among others in order 
to attract FDI in the country (National Tax Research Center, 2015). Based on the Investment Climate Statement, the Philippines' growing middle class, strong domestic demand, and stable political environment, paired with positive growth of gross domestic product, make the country an increasingly attractive destination for foreign direct investment.

Economic growth accelerates and augments foreign direct investment inflow into the host country (Nelson, 2012). Hence, there is need for continuous increase and growth of the country's real Gross Domestic Product (GDP). Foreign direct investment in a country will increase if the investors are certain that the host country is supportive of the necessary support that investors are needed in order to operate in a market. This can be achieved if the government creates an environment that offers attractive incentives for production activities of foreign investors. Investors seek those countries that are viable and prepared to enforce laws that induce competition among market players, have transparent rules for private and public entities, offering sustainable incentive, and have productive resources that will fuel their economic growth (Jian \& Kamara, 2017).

\section{Literature Review}

\subsection{Theoretical Foundations}

One of the theories on macroeconomic level determinants of FDI states that the size of the domestic market is a fundamental determinant of FDI. The market size hypothesis asserts that the amount of FDI in a host country depends on market size, which is also the most robust FDI determinant (Demirhan \& Masca, 2008). Foreign investments will move to countries with bigger markets, developing markets, and higher purchasing power, thus enabling firms to receive higher returns on their capital and increased profits from their investments. Market size is measured by GDP or by sales of multinational firms in that country (Faeth, 2009). Mughal and Akram (2011) study in Pakistan, showed that market size, GDP, had a significant positive effects on inflow of FDI. A percentage increase in GDP leads to an increase in FDI inflow by 5.6 percent. Similar to the study of Nantharath and Kang (2019) human capital through education plays an important role in the development of foreign direct investment in a country.

\subsection{Impact of Education on Economic Growth}

One of the most essential factors of economic growth is human capital, in which the role of education and innovation is very important. Microeconomic analysis provides estimation of the effect of education on an individual's income, while macroeconomic analysis investigates the causal relationship between education quantity or education quality with economic growth. Pelinescu (2014) revealed a positive statistically significant relationship between GDP per capita and the innovative capacity of human capital evidenced by the number of patents, and qualification of employees measured by secondary education.

Changzheng and Jin (2008) emphasized the existing relationship between educational equity and the quality of economic growth in China. Results showed that the educational equity is significantly and positively related to the quality of economic growth. Educational equity does not only promote social development, but also harmonious economic growth. The mechanism that educational equity promotes the quality of economic growth is that it improves human capital accumulation and optimizes the structure of human capital. It speeds up technology improvement and ultimately reflects on the performance of total factor productivity improvement.

To empirically investigate the impact of human capital on economic growth, Arabi and Abdalla (2013) used a simultaneous equation model that linked human capital school attainment and investment in education to economic growth, total productivity, and foreign direct investment. Based on a three-stage least squares technique, the empirical results of the paper reflected that: the quality of education has a determinant role in economic growth; economic output was influenced more by highly educated people than secondary educated ones. Also, there was an adverse effect of the ratio of government total expenditure to GDP, on the ratio of foreign direct investment to GDP, which can be attributed to the concentration of the government on consumption activities rather than productive activities.

Liu and Wang (2016) emphasized the positive impact of higher education on economic growth. However, primary education and secondary education do not have a significant impact on economic growth.

Increasing the number of students who finish secondary education and eventually complete a postsecondary degree would create significant benefits for individuals, communities, states, and the nation as a whole. The demonstrated benefits include increased lifetime earnings and tax revenues, increased purchases such as homes and cars, and lower unemployment rates. The benefits also relate to improvements in quality of life such as decreased crime and incarceration rates and improved health conditions and outcomes. It is suggested that a significant part of the measured effect of education on crime can be attributed to the increase in wages associated with schooling. 


\subsection{Impact of Road Infrastructure on Economic Growth}

Estache and Garsous (2012) argued that the estimated growth effects of transport investments on developed countries have not been very strong since the transport stocks were already mature. The main impact at advanced stages of development as to come from quality, from addressing bottlenecks or from capturing new networks or effects which have not been internalized in older designs of the transport networks. For developing countries, roads are needed to catch up with the rest of the world. Roads are essential to reduce differences across regions within countries. The paper emphasized that for country specific studies, the overall results are not always as clear cut, because econometric methodologies cannot easily fully capture the gains from marginal, or sometimes more significant, redesigns of the transport networks to fully internalize network externalities. These methodologies seldom pick up fully the country level gains from intermodal interactions and from increased competition or improved integration.

Similarly, transportation infrastructure through construction of a road system could lead to economic growth, especially to export industries and tourism. Road system plans will establish the economic situation of the people. Hence, economic gain will play an important role towards a peaceful and developed economy (McCune \& Jain, 2003). However, there are empirical studies that show poor (Rye, 2017), negative (Kodongo \& Ojah, 2016), and insignificant (Kayode, Babatunde, \& Abiodun, 2013) relationship between road infrastructure and economic growth. The low level of transport infrastructure investment, no discernible transport policy, high road traffic and accidents, and unintended negative externalities, lead to negative economic growth.

Rye (2017) considered developed countries with developed transport networks like Scotland, found out that there is no high quality empirical evidence that transport infrastructure investment will boost economic growth of a country. There is a weak correlation between a new surface transport infrastructure and the GDP. Also, there is an extremely weak link between journey times, time spent travelling, and economic growth, as average speed of personal travel remained remarkably constant regardless of the transportation infrastructure. Economic growth rates show no correlation with changes in average speed, because the results showed that countries travelling fastest are not the wealthiest.

Infrastructure is a necessary condition for growth but by far not a sufficient one. In mature economies, new infrastructure generally does not raise aggregate output and productivity in the short to medium run, but is likely to affect the spatial allocation of economic actors. A new highway can make certain regions more attractive, at the detriment of others. Even though road infrastructure investments do not raise income per capita in the short and medium run; it does not imply that these investments are not efficient. In the empirical analysis, the removal of a severe bottleneck would show up as the strongest impact. For the economy, however, it may be more efficient to ensure that bottlenecks do not emerge in the first place, rather than removing them later on (Fretz, 2014).

\subsection{Impact of Economic Growth on Foreign Direct Investment}

The FDI is imperative for development as it plays a significant role in bringing about capital required to increase production processes, and harnessing and transforming the resources of the country. Jadhav (2012) studied the determinants of FDI in Brazil, Russia, India, China, and South Africa (BRICS) economies. The FDI was the dependent variable, while GDP for market size, inflation rate for macroeconomic stability, trade openness, corruption, rule of law, and political stability were the independent variables. The results indicated that market size measured by real GDP is a significant determinant of FDI, which implies that most of the investment in BRICS is motivated by a market-seeking purpose.

Gharaibeh (2015) emphasized that the determinants of FDI according to the empirical studies are classified into two sides: demand side and supply side. The demand side includes variables related to the host country, while the supply side includes variables related to the investing company itself. Country-specific variables possibly include market size, economic growth, balance of payments, inflation rates, tax levels, political stability, and government policies on foreign investment.

Nelson (2012) and He and Choi (2020) empirically assessed the relationship between FDI and economic growth. The two main variables of the study were economic growth and FDI. The lagged value of GDP was used as the proxy for economic growth. The study revealed that there is a positive relationship between FDI and economic growth and that increasing economic growth accelerates and augments foreign direct investment inflow into India.

\section{Methodology}

To achieve the objectives of this study, the paper used the quantitative research design applying inferential statistics. Descriptive design was used to describe and explain the behavior of the determinants. The inferential 
statistics was used to measure the relationship between the explanatory variables, as conditioned by economic growth, to the FDI.

\subsection{The Regression Model}

To find out the interplay between education and local roads, as conditioned by economic growth, on the FDI in the Philippines, panel data regression analysis was employed. Panel data regression analysis was performed using three estimation techniques: pooled least square model, fixed effect model, and random effect model. The two-stage least squares model uses instrument variables uncorrelated with the error term to estimate the model parameters. These IVs are correlated to the endogenous variables but not with the error term of the model.

First Stage:

$G R D P=\beta_{0}+\beta_{1} H E_{\mathrm{it}}-\beta_{2} L R_{\mathrm{it}}+\varepsilon_{\mathrm{it}}$

Second Stage:

$F D I=\beta_{0}+\beta_{1} \hat{G} \hat{R} \check{D} P_{\mathrm{it}}+\beta_{2} \hat{G} \hat{R} \check{D} P_{\mathrm{t}-1}+\varepsilon_{\mathrm{it}}$

where: GRDP refers to economic growth as measured by gross regional domestic product, $\mathrm{HE}$ as higher education graduates, LR is the local road Investments, FDI is the

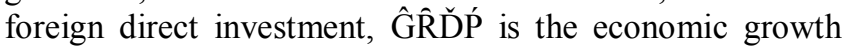
Estimates, $\hat{\mathrm{G}} \hat{\mathrm{R}} \mathrm{D}_{\mathrm{t}-1}$ is the lagged economic growth Estimates, $\beta_{\mathrm{s}}$ are parameter estimates, i refers to Regions, $t$ refers to time period, and $\varepsilon$ is the error term.

\subsubsection{The Pooled Least Square Model}

The pooled least square model assumes that coefficients are constant across time and individuals (Gujarati, 2005). This is the simplest approach as it disregards the space and time dimensions of the pooled data and just estimates the usual ordinary least square regression.

First Stage:

$G R D P=\beta_{0}+\beta_{1} H E$ it $-\beta_{2} L R$ it $+\varepsilon_{\text {it }}$

Second Stage:

$F D I=\beta_{0}+\beta_{1} \hat{G} \hat{R} \check{D} \dot{P}^{\mathrm{it}}+\beta_{2} \hat{G} \hat{R} \check{D} \dot{P}_{\mathrm{t}-1}+\varepsilon_{\mathrm{it}}$

Despite its simplicity, pooled regression may distort the true picture of the relationship of FDI and changes in education and local roads, as conditioned by economic growth, across 16 regions.

\subsubsection{Fixed Effect Model (FEM)}

The FEM is used between individual effects and if the explanatory variables are correlated:
First Stage:

$G R D P=\beta_{0}+\beta_{1} H E_{\mathrm{it}}-\beta_{2} L R_{\mathrm{it}}+\sum_{i=1}^{17} R+\varepsilon_{\mathrm{it}}$

Second Stage:

$F D I=\beta_{0}+\beta_{1} \hat{G} \hat{R} \check{D} \dot{P}_{\mathrm{it}}+\beta_{2} \hat{G} \hat{R} \check{D} \dot{P}_{\mathrm{t}-1}+\sum_{\mathrm{i}=1}^{17} \mathrm{R}+\varepsilon_{\mathrm{it}}$

where: $\mathrm{R}$ is dummy variable for 17 regions.

\subsubsection{Random Effect Model (REM)}

The REM is effective if the explanatory variables are not correlated and there is a random individual effect of the entities.

First Stage:

GRDP $=\beta_{0}+\beta_{1} \mathrm{HE}_{\mathrm{it}}-\beta_{2} \mathrm{LR}_{\mathrm{it}}+\mathrm{U}_{\mathrm{it}}+\varepsilon_{\mathrm{it}}$

$\mathrm{FDI}=\beta_{0}+\beta_{1} \hat{\mathrm{G}} \hat{\mathrm{R}} \check{\mathrm{D}} \dot{P}_{\mathrm{it}}+\beta_{2} \hat{\mathrm{G}} \hat{\mathrm{R}} \check{\mathrm{D}} \dot{\mathrm{P}}_{\mathrm{t}-1}+\mathrm{U}_{\mathrm{it}}+\varepsilon_{\mathrm{it}}$

Except for the test for stationarity using the Levin, Lin and Chu procedure and the Hausman test, all the other statistical tests used in this study were taken from the book of Gujarati (2003). To examine which model is better: the fixed effect model or the random effect model, the Hausman test was utilized.

The test is presented as follows:

$\mathrm{H}=\left(\beta^{\mathrm{FE}}-\beta^{\mathrm{FE}}\right)\left[\operatorname{var} \beta^{\mathrm{FE}}-\beta^{\mathrm{FE}}\right]-1\left(\beta^{\mathrm{FE}}-\beta^{\mathrm{FE}}\right)$

Where: BFE is the fixed effect estimator, and BRE is the random effect estimator. If the Hausman statistic is significant at a specified level of significance, the fixed effect model is the more appropriate model. Otherwise, the random effect model is better (Baltagi, 2005).

\section{Results and Discussion}

\subsection{Descriptive Statistics}

Table 1 shows the historical data on FDI by region from 2012 to 2015. Majority of the FDI was channeled to Region IV-A, III, VII, National Capital Region (NCR), and Cordillera Administrative Region (CAR). The total approved foreign investment recorded in 2012 was the highest since 2007. The majority of investment inflows were in manufacturing, retail, real estate, mining, and the information and communication sectors. Region III has the highest foreign investment in 2012 and 2013. It was followed by Region IV-A and then NCR. However, from 2014 to 2015, Region IV-A has the highest FDI followed by NCR, Region III, and CAR. 
Table 1: Total Philippine foreign direct investments

\begin{tabular}{|c|c|c|c|c|}
\hline REGIONS & $\mathbf{2 0 1 2}$ & $\mathbf{2 0 1 3}$ & $\mathbf{2 0 1 4}$ & $\mathbf{2 0 1 5}$ \\
\hline NCR & 58,349 & 55,220 & 52,069 & 34,137 \\
\hline CAR & 1,620 & 1,533 & 1,502 & 26,311 \\
\hline I & 1,917 & 1,814 & 0 & 725 \\
\hline II & 1,236 & 1,170 & 341 & 595 \\
\hline III & 83,480 & 79,002 & 25,614 & 22,714 \\
\hline IV-A & 63,995 & 60,562 & 87,189 & 115,647 \\
\hline IV-B & 2,431 & 2,300 & 2,264 & 3,842 \\
\hline V & 2,413 & 2,284 & 0 & 2,020 \\
\hline VI & 6,940 & 6,568 & 1,636 & 7,194 \\
\hline VII & 13,584 & 12,856 & 7,229 & 11,697 \\
\hline VIII & 6,271 & 5,935 & 723 & 38 \\
\hline IX & 564 & 534 & 0 & 0 \\
\hline X & 21,842 & 20,670 & 2,660 & 3,869 \\
\hline XI & 20,078 & 19,001 & 505 & 1,733 \\
\hline XII & 844 & 798 & 2,995 & 6,462 \\
\hline XIII & 3,380 & 3,199 & 1,648 & 3,114 \\
\hline ARMM & 593 & 561 & 579 & 0 \\
\hline
\end{tabular}

Source: Philippine Statistical Authority (2016)

Most of the investments in Region IV-A were intended to finance projects in real estate activities and manufacturing. The region received almost half of the foreign investment commitments in the whole year of 2015. The second largest amount of FDI was intended for NCR. Most of the funded projects for NCR were in Administrative and Support Service Activities. On the other hand, investments funded for Region III were for electricity, gas, steam and air conditioning supply, as well as real estate. Foreign investment ventures for CAR and Region VII were mostly in manufacturing.

The total approved FDI has been fluctuating with major ups and downs, as shown in Figure 1. From 2012 to 2015, FDI inflow in 2012 was the highest. The Philippines showed great improvement in the area of market access, moving up 50 places from 64th in 2010 to 14th in 2012. The country's strong macroeconomic fundamentals attracted investors despite the concerns over crisis in some parts of Europe and the moderation in global activity.

However, there was a slight decline in 2013 because the country was affected by the reversal of investments in relation to the Fed taper, as stated by the Bank of the Philippine Islands. In addition, restrictions on foreign investments hampered the inflow of investments. The Philippine Constitution limits foreign investors to 40 percent ownership of a corporation. Most of the decline was from the commitments intended for projects in the manufacturing industry. In the same manner, the mining and quarrying industry was also greatly affected.

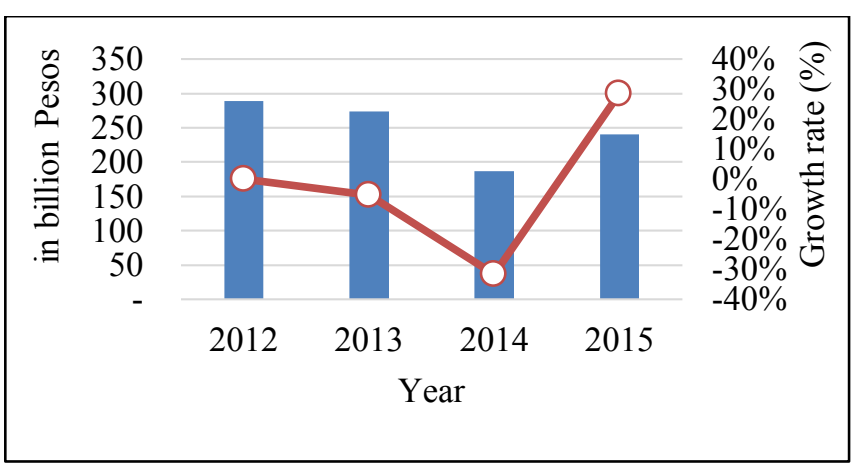

Figure 1: Total Philippine foreign direct investments

Foreign direct investments grew by 28 percent in 2015 . Bangko Sentral ng Pilipinas (2016) emphasized that the increase was due to the maintained investor confidence in the country's sound macroeconomic fundamentals. Funds were put into manufacturing; water supply, sewerage, waste management and remediation; financial and insurance; real estate; and mining and quarrying. Foreign investments in agriculture, forestry, and fishing industries also increased.

Historical data on higher education graduates by region from 2012 to 2015 is shown in Table 2. From 2012 to 2015, NCR always had the highest number of higher education graduates with $113,664,115,042,119,376$, and 128,432, respectively. The least number of graduates came from ARMM with 4,994, 5,279, 6,440, and 8,130, respectively.

Second to the highest were Region III with an average of 49,736 higher education graduates, followed by Region IV-A with an average of 49,803 graduates. Increased number of graduates for the said regions was due to interprovincial migration. Region III and IV-A were considered migrant-gaining provinces, wherein people from other regions chose to live within these regions to earn a living, start a family, buy own house, and to finish studies. Region VI and Region VII also had high graduates with an average of 41,017 and 39,207, respectively.

On the other hand, Region XIII and ARMM had the lowest number of graduates with an average of 6,397, 6,710, 7,502 , and 8,762 higher education graduates in 2012, 2013, 2014 , and 2015, respectively. The low number of graduates was due to the long time conflict between the government and rebels. During armed conflicts, schools were used as refugee centers, thus classes were disrupted. Likewise, children and teachers suffered from trauma which prevented them from effectively learning or teaching. Also, some students became members of rebel groups, so they did not have the chance to finish high school and college. 
Table 2:Higher education graduates in the Philippines

\begin{tabular}{|c|c|c|c|c|}
\hline REGION & $\mathbf{2 0 1 2}$ & $\mathbf{2 0 1 3}$ & $\mathbf{2 0 1 4}$ & $\mathbf{2 0 1 5}$ \\
\hline NCR & 113,664 & 115,042 & 119,376 & 128,432 \\
\hline CAR & 14,331 & 14,947 & 15,627 & 17,230 \\
\hline I & 24,501 & 21,969 & 22,145 & 25,102 \\
\hline II & 18,401 & 19,162 & 23,500 & 19,118 \\
\hline III & 47,933 & 52,837 & 51,591 & 46,582 \\
\hline IV-A & 47,254 & 48,967 & 50,330 & 52,660 \\
\hline IV-B & 8,299 & 7,797 & 9,368 & 10,038 \\
\hline V & 25,584 & 24,659 & 24,410 & 27,850 \\
\hline VI & 43,868 & 38,737 & 38,758 & 42,704 \\
\hline VII & 35,037 & 38,340 & 39,588 & 43,863 \\
\hline VII & 16,405 & 16,508 & 17,457 & 18,600 \\
\hline IX & 12,769 & 14,815 & 13,369 & 14,813 \\
\hline X & 18,360 & 22,303 & 24,029 & 23,480 \\
\hline XI & 17,018 & 17,379 & 17,626 & 19,857 \\
\hline XII & 13,921 & 14,449 & 14,771 & 14,718 \\
\hline XIII & 7,800 & 8,141 & 8,564 & 9,393 \\
\hline ARMM & 4,994 & 5,279 & 6,440 & 8,130 \\
\hline
\end{tabular}

Source: Commission on Higher Education (2019)

Table 3: Local road investments by region, in billion Philippine peso

\begin{tabular}{|c|c|c|c|c|}
\hline REGIONS & $\mathbf{2 0 1 2}$ & $\mathbf{2 0 1 3}$ & $\mathbf{2 0 1 4}$ & $\mathbf{2 0 1 5}$ \\
\hline NCR & 0 & 23 & 64 & 41 \\
\hline CAR & 152 & 1868 & 202 & 580 \\
\hline I & 493 & 617 & 839 & 0 \\
\hline II & 71 & 160 & 413 & 1417 \\
\hline III & 493 & 115 & 299 & 125 \\
\hline IV-A & 613 & 347 & 700 & 1135 \\
\hline IV-B & 414 & 30 & 379 & 217 \\
\hline V & 1078 & 104 & 380 & 350 \\
\hline VI & 110 & 29 & 505 & 748 \\
\hline VII & 201 & 4 & 56 & 309 \\
\hline VII & 435 & 284 & 154 & 48 \\
\hline IX & 35 & 1615 & 442 & 115 \\
\hline X & 764 & 95 & 37 & 956 \\
\hline XI & 848 & 944 & 1465 & 162 \\
\hline XII & 416 & 510 & 400 & 402 \\
\hline XIII & 1604 & 1880 & 2825 & 2000 \\
\hline ARMM & 964 & 470 & 54 & 2479 \\
\hline
\end{tabular}

Source: Department of the Interior and Local Government (2019)
Higher education graduates positively increased from 2012 to 2015. The NCR had the highest higher number of higher education graduates, followed by Region III, IV-A, and VII. Said regions had the most number of distributions of higher education institutions.

Historical data on national government expenditures on local roads by region from 2012 to 2015 is shown in Table 3 . Region XIII had the highest local road investments in 2012, 2013, and 2014. Funds for Region XIII were used for the construction of five farm-to-market roads under the Philippine Rural Development Project, that would help in the development of agri-enterprises such as abaca and rubber production/marketing in Agusan del Norte and Agusan del Sur, respectively. On the other hand, there was no allotted fund for local roads in NCR, as funds were allocated for drainage canals and training and capacity building of LGUs and their constituents.

Table 4 shows the historical data on GRDP from 2012 to 2015. The real GRDP was measured at constant 2000 prices. The NCR had the highest real GRDP followed by Regions IV-A, III, VII, and VI. On the contrary, ARMM had the lowest real GRDP followed by Regions XIII, and IV-B. Majority of real GRDP or the goods and services produced domestically, came from the NCR and Region IV-A. The growth was attributed to the higher growth of the Industry sector. The increase in output for Region $\mathrm{V}$ in 2013 was attributed to the service sector, the largest contributor to the economic performance of the region.

In 2014, the service sector accounted for the largest share of total output in Region III. While Region XIII's impressive growth was fueled by the expansion of its service sector and the rebound of its agriculture sector. On the other hand, Region VIII was the only region which suffered from contraction in output. This was mainly due to the lingering effects of Super Typhoon Yolanda which hit the region in November 2013 and was heavily felt in 2014.

In 2015, the impressive economic performance of Region IX was brought about by the accelerated growth of its industry and services sector. The manufacturing and construction sector also contributed. However, ARMM experienced a decrease in domestic output due to the deceleration of services and of agriculture, hunting, forestry and fishing.

Notwithstanding the damage brought about by the series of natural calamities that hit the country in 2013, the real GRDP still increased. The output was driven by the services sector, particularly, trade and real estate, renting and business activities, and by the accelerated performance of the manufacturing sector (Philippine Statistics Authority, 2013). 
Table 4: Real gross regional domestic product, in billion pesos

\begin{tabular}{|c|c|c|c|c|}
\hline REGIONS & $\mathbf{2 0 1 2}$ & $\mathbf{2 0 1 3}$ & $\mathbf{2 0 1 4}$ & $\mathbf{2 0 1 5}$ \\
\hline NCR & 2,250 & 2,455 & 2,601 & 2,772 \\
\hline CAR & 118 & 125 & 129 & 133 \\
\hline I & 198 & 211 & 225 & 236 \\
\hline II & 113 & 120 & 129 & 134 \\
\hline III & 586 & 612 & 669 & 704 \\
\hline IV-A & 1,098 & 1,171 & 1,231 & 1,304 \\
\hline IV-B & 109 & 111 & 120 & 122 \\
\hline V & 126 & 137 & 143 & 155 \\
\hline VI & 258 & 267 & 281 & 304 \\
\hline VII & 398 & 427 & 461 & 483 \\
\hline VIII & 143 & 150 & 146 & 152 \\
\hline IX & 132 & 137 & 146 & 157 \\
\hline X & 238 & 251 & 268 & 283 \\
\hline XI & 241 & 257 & 281 & 304 \\
\hline XII & 171 & 185 & 197 & 203 \\
\hline XIII & 78 & 84 & 92 & 96 \\
\hline ARMM & 47 & 49 & 51 & 50 \\
\hline I & & & \\
\hline
\end{tabular}

Philippine Statistics Authority (2016)

In 2014, the economy grew, but the growth rate was less than the previous year. The deceleration of the country's performance was due to the slower growth of the industry and services sectors. Similarly, in 2015, the economy performed well, however at a slower pace. The slower growth of exports was cited by the PSA as one of the factors behind the slower growth in the country's real GRDP.

\subsection{Regression Analysis}

The results of the statistical tests including regression analyses and interpretations are presented and discussed in the succeeding sections.

The stationarity of the panel data was determined through the Levin, Lin and Chu Unit Root Test. The test of stationarity shows that economic growth and local road investments were all stationary at level, with probability value of less than 5\%. Conversely, FDI and higher education graduates were stationary at 1st difference, with a probability value of less than $5 \%$. The respective Levin, Lin $\&$ Chu statistic for FDI, economic growth, higher education graduates, and local road investments were 4.009, 140.143, 3.958 , and 5.146, respectively.

The F-test and Hausman Test were used by this study to test if the instruments are valid. Since, the F-statistic is greater than ten, it is concluded that the instrument variables are relevant and that the error is not dependent on the instruments.

This study directly compared the Ordinary Least Square (OLS) and Two Stage Least Square (TSLS) estimates through regression. The test for instrument validity shows that the probability of DWI which is the estimates of ordinary least square and two-stage least squares is 0.000 . The probability is less than 0.05 , the first null hypothesis that the ordinary least square model does not significantly differ from the two-stage least squares model, is rejected. Because the ordinary least square and two-stage least squares estimates differ significantly, it is concluded that the instrument variables are exogenous. The two-stage least squares model is much appropriate than the ordinary least square model.

To test the significance of the hypothesized effects of higher education graduates and local road investments, as conditioned by economic growth, on FDI, panel regression analysis was performed. This study utilized three approaches in panel regression models, namely the Fixed Effect Model, Random Effect Model, taking into account the individual differences across the regions, and the Random Effect Model and Pooled Least Square Regression which assumed the absence of possible regional differences. The results are described as follows:

The coefficient of determination, R2, at 0.588 implied that 58.80 percent of the variations in foreign direct investment was explained by the variations in higher education graduates and local road investments, as conditioned by economic growth. The computed t-stat of 1.775 exceeded the 1.303 critical t-value (see Table 5). Thus, the third null hypothesis that foreign direct investment is not significantly affected by higher education graduates, as conditioned by economic growth, is rejected. However, local road investments were not statistically significant at ten percent level of significance.

Table 5: Pooled Least Square Regression

\begin{tabular}{|c|c|}
\hline $\begin{array}{lr}\text { FDI }= & -15875.227 \\
\text { t-stat } & (-0.245) \\
\text { p-values } & (0.808)\end{array}$ & $\begin{array}{cc}+5.251 H E- & 6.135 L R \\
(1.775) & (-0.722) \\
(0.082) & (0.474)\end{array}$ \\
\hline $\begin{array}{r}\mathrm{R}^{2}=0.588 \text { Adjusted } \\
\text { DW Sta }\end{array}$ & $\begin{array}{l}R^{2}=0.562 \quad F=78.956 \\
t=1.788\end{array}$ \\
\hline \multicolumn{2}{|c|}{$\begin{array}{l}\text { Critical Values: Durbin Watsons: } \\
\text { t-value }{ }_{(50: \alpha=0.10)}=1.303 \quad \operatorname{du}(2,51)=1.445\end{array}$} \\
\hline
\end{tabular}

The F-statistic of 78.956 exceeded the critical F-value of 3.230 at five percent level of significance. Hence, the third null hypothesis that foreign direct investment is not significantly affected by higher education graduates and local road investments, as conditioned by economic 
growth, when taken collectively, is rejected. The regression model is statistically significant and that a unit change in the higher education graduates and local road investments, as conditioned by economic growth, when taken collectively, affect a unit change in FDI in the Philippines.

The computed d-statistic of 1.788 is greater than the critical dL of 1.285 and critical dU of 1.445 at $k^{\prime}=2$ and $\mathrm{n}=51$. Since the critical upper limit is less than the computed d statistic, $\mathrm{dU}<\mathrm{d}$, the null hypothesis is accepted that is, there is no first-order autoregressive serial correlation. Moreover, the computed d-statistic is less than 2.555 which is $4-\mathrm{du}$, indicating the absence of positive or negative autocorrelation. Thus, the regression model is reliable and efficient.

\subsection{Fixed Effect Model}

The regression results using the FEM are shown below. The coefficient of determination, R2, at 0.882 implied that 88.20 percent of the variations in FDI was explained by the variations in higher education graduates and local road investments, as conditioned by economic growth. The remaining 11.8 percent was attributed to other factors that were not included in the model.

The computed t-stat of 12.405 and 10.756 exceeded the 1.684 critical t-value (see Table 6). Thus, the third null hypothesis that foreign direct investment is not significantly affected by the higher education graduates and local road investments, as conditioned by economic growth, is rejected. Moreover, the F-statistic of 104 exceeded the critical F-value of 3.230 at five percent level of significance. Hence, the third null hypothesis that foreign direct investment is not significantly affected by higher education graduates and local road investments, as conditioned by economic growth,when taken collectively, is rejected.The regression model is statistically significant and that a unit change in higher education graduates and local road investments, as conditioned by economic growth, when taken collectively, affect a unit change in foreign direct investment in the Philippines.

The computed d-statistic of 2.669 is greater than the critical dL of 0.625 and critical dU of 2.387 at $k^{\prime}=18$ and $\mathrm{n}=51$. Since the critical upper limit is less than the computed d statistic, $\mathrm{dU}<\mathrm{d}$, the null hypothesis is accepted that is, there is no first-order autoregressive serial correlation. However, the computed d-statistic is greater than 1.613 which is $4-\mathrm{du}$, thus, it falls under the indecisive zone. Given $4-\mathrm{dU}<\mathrm{d}<4-\mathrm{dL}$, the modified d-test was applied. The condition to be satisfied this time is $4-\mathrm{d}<\mathrm{dU}$. In values, this gives $4-2.669<2.387$ which results to 1.331 $<2.387$. Hence, there is no positive or negative autocorrelation. The regression model is reliable and efficient.
Differential dummies showed that CAR, Regions I, II, IV-B, V, VIII, IX, X, XI, XII, XIII, and ARMM had higher FDI, as conditioned by economic growth, than the reference region or Region IV-A.

Table 6: Fixed Effect Model Test

\begin{tabular}{|c|c|c|c|}
\hline Variable & Coefficient & t-Statistic & Prob. \\
\hline Constant & $-187,346.22$ & -2.695 & 0.011 \\
\hline $\mathrm{HE}$ & 8.758 & 12.405 & 0.000 \\
\hline LR & -0.002 & -10.756 & 0.000 \\
\hline $\mathrm{R} 2$ & $-806,519.96$ & -9.238 & 0.000 \\
\hline R3 & $636,735.65$ & 6.835 & 0.000 \\
\hline R4 & $331,742.71$ & 2.49 & 0.018 \\
\hline R5 & $250,023.30$ & 2.225 & 0.033 \\
\hline R6 & $-169,461.21$ & -2.79 & 0.009 \\
\hline R7 & $159,026.05$ & 2.296 & 0.028 \\
\hline R8 & $28,694.90$ & 0.442 & 0.662 \\
\hline R9 & $-59,488.42$ & -0.812 & 0.423 \\
\hline $\mathrm{R} 10$ & $-129,070.76$ & -2.086 & 0.045 \\
\hline R11 & $73,603.48$ & 1.085 & 0.286 \\
\hline $\mathrm{R} 12$ & $229,742.24$ & 1.866 & 0.071 \\
\hline R13 & $76,655.44$ & 0.837 & 0.409 \\
\hline R14 & $232,842.97$ & 2.053 & 0.048 \\
\hline R15 & $163,796.21$ & 2.518 & 0.017 \\
\hline R16 & $631,708.30$ & 6.134 & 0.000 \\
\hline R17 & $361,707.19$ & 1.993 & 0.055 \\
\hline \multicolumn{2}{|c|}{$\mathrm{R} 2=0.882$} & \multicolumn{2}{|c|}{ F-Statistics $=104.321$} \\
\hline \multicolumn{2}{|c|}{ Adjusted R2 $=0.816$} & \multicolumn{2}{|c|}{ DW Statistics $=2.669$} \\
\hline
\end{tabular}

On the other hand, NCR and Region III, VI, and VII had fewer FDI, as conditioned by economic growt h, compared with Region IV-A.

To determine if there is a significant difference in the FDI, as conditioned by economic growth, of each region, the Fixed Effect Test was used. Based on the test for fixed effect result, the probability is less than the five percent significance level. Therefore, the fourth null hypothesis that there are no significant differences in the coefficient of each region, is rejected.

\subsection{Random Effect Model}

Side by side with the FEM, panel data regression using the REM was also performed. The computed t-stat of 0.184 and 0.258 showed that the model was not statistically significant at five percent level or even at ten percent level of significance as shown in Table 7. 
Also, the coefficient of determination, R2, is 0.005 , implied that 0.500 percent of the variations in FDI was explained by the variations in higher education graduates and local road investments, as conditioned by economic growth. Hence, REM is not a good model to use for the study.

Table 7: Random Effect Model Regression

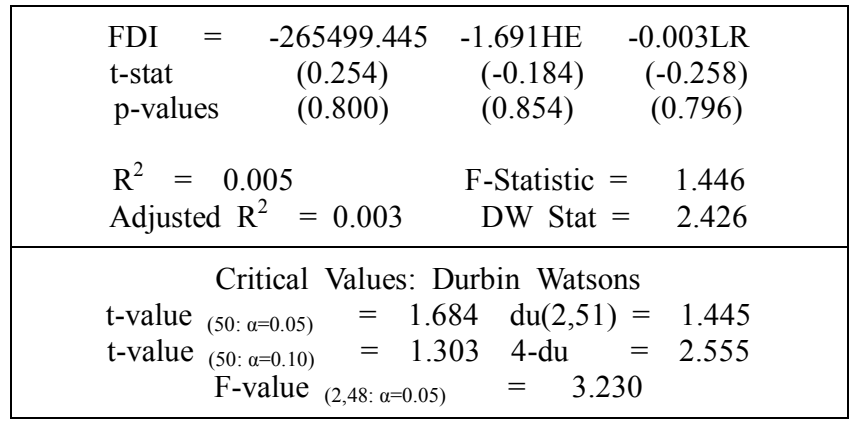

To identify which is the more appropriate model, Fixed Effect Model or Random Effect Model, the Hausman Test was conducted. The probability of 0.956 was much higher than the five percent significance level, the null hypothesis that the Fixed Effect Model is not the appropriate panel regression approach to be used, is accepted. Although the result of the test is much higher than five percent level of significance, which means that the two model are indifferent, it does not necessarily follow that the random effect estimator is safely free from bias, and therefore to be preferred over the fixed effect estimator. In most applications, the true correlation between the covariates and unit effects is not exactly zero (Clark \& Linzer, 2012).

Using the FEM, 88.20 percent of the variations in FDI was explained by the variations in higher education graduates and local road investments, as conditioned by economic growth, as compared to the REM which is only 0.500 percent. Also, variables were statistically significant with the FEM than with the REM. Hence, this paper adopted the Fixed Effect Model as the appropriate model.

\section{Conclusions and Recommendations}

Based on the aforementioned findings of this study, the following conclusions were derived: Higher education graduates and local road investments were significant determinants of economic growth. Higher education graduates obtained a strong positive correlation to economic growth. This study proved the stated theory that human capital through education contributes to economic growth. Human capital can directly participate in production as a productive factor (Romer, 1990) and can contribute to raising technical progress since education eases the innovation, diffusion, and adoption of new technologies. In addition, countries with high levels of skilled labor are more likely to be attractive to FDI that are associated with high value-added industries or efficiency and productive seeking FDIs.

On the other hand, local road investments obtained a weak and negative correlation to economic growth. The low level of transport infrastructure investment, no strict enforcement of transport policy, road accidents, and major traffic, lead to negative economic growth. More roads will reduce congestion and improve performance. However, the increase above a certain threshold will no longer affect the GDP and competitiveness, as it will not address bottlenecks (Sanchez-Robles, 1998).

The study also showed that there is moderate positive correlation between FDI and economic growth. Therefore, for every increase in economic growth, FDI inflow increases.

The regression results obtained from the FEM, suggested that, statistically, FDI was significantly affected by the higher education graduates and local road investments, as conditioned by economic growth. Among the three approaches of panel regression, the Fixed Effect Model is the most appropriate model to use in measuring the interplay between education and local roads, conditioned by economic growth, on foreign direct investments in the Philippines.

The result of the FEM denoted that the FDI, as conditioned by economic growth, differed among regions. The CAR, Regions I, II, IV-B, V, VIII, IX, X, XI, XII, XIII, and ARMM showed a higher FDI, while all other regions displayed a lesser FDI, as conditioned by economic growth, compared with the reference region. The NCR, Region III, VI, and VII already have high higher education graduates and high real GRDP. Hence, it could be possible that policymakers decided to channel the FDI to other regions.

Based on the conclusions drawn in this study, the paper offers the following recommendations: Strengthening the higher educational systems of the country will really be beneficial not just to economic growth but to the foreign direct investments inflow as well. Assessing the impact of different reform programs as well as scholarship grants for higher education may be done, to identify which of the reforms and grants positively affects the economy.

Full and strict implementation of transport policies of each local government of the 17 regions must be done to address road problems like accidents, road congestion, and the worsening traffic condition. The conduct of research studies to identify the adequacy of local road infrastructure for business and industry of local government units is also recommended.

Government funds for higher education and local roads should be optimized and efficiently utilized to address 
investments for these sectors, which will then aid in the continuous increase of the country's gross domestic product. To attract foreign investors, the government should create an enabling environment and incentives for production activities.

Other determinants of foreign direct investments may be considered in future research. Moreover, future studies may be undertaken similar to this paper while considering other relevant variables and methods which were not covered in this study.

\section{References}

Arabi, K. M., \& Abdalla, S. S. (2013). The impact of human capital on economic growth: empirical evidence from Sudan. Research in World Economy, 4(2), 48-50.

Bangko Sentral ng Pilipinas. (2016). Report on regional economic developments in the Philippines. Department of Economic Research, Regional Monetary Affairs Sub-Sector. Retrieved December 28, 2019, from http://www.bsp.gov.ph/publications/regular_regional.a

Changzheng, Z. \& Jin, K. (2008). An empirical study on the relationship between educational equity and the quality of economic growth in China: 1978-2004. Procedia Social and Behavioral Sciences (pp.189-194). Beijing, China: Elsevier.

Clark, T. S., \& Linzer, D.A. (2015). Should I use fixed or random effects? Political Science Research and Methods, 3(2), 399408.

Commission on Higher Education. (2019). Higher Education. Retrieved December 22, 2019, from www.ched.gov.ph.

Demirhan, E., \& Masca, M. (2008). Determinants of foreign direct investment flows to developing countries: a cross-sectional analysis. Prague Economic Paper, 2008(4), 356-369.

Department of Budget and Management. (2019). Budget and Management. Retrieved December 21 2019, from www.dbm.gov.ph.

Department of Interior and Local Government. (2019). Local Government. Retrieved December 20, 2019, from:www.dilg.gov.ph.

Estache, A. \& Garsous, G. (2012). The impact of infrastructure on growth in developing countries. IFC Economic Notes, Note 1 Worldbank, Washington, DC.

Faeth, I. (2009). Determinants of foreign direct investment - a tale of nine theoretical models. Journal of Economic Surveys, 23(1), 165-196

Fretz, S. (2014). Infrastructure and economic growth (Doctoral Dissertation). University of St. Gallen, Switzerland.

Gharaibeh, A. O. (2015). The determinants of foreign direct investment-empirical evidence from Bahrain. International Journal of Business and Social Science, 6(8), 95-106.

Gujarati, D. N. (2003). Basic Econometrics (4th ed.). New York, NY: McGraw-Hill Company.

He, Y. \& Choi, B.-R. (2020). China's outward foreign direct investment patterns evidence from Asian financial markets. Journal of Asian Finance, Economics and Business, 7(2), 157168. https://doi.org/10.13106/jafeb.2020.vol7.no2.157
Jadhav, P. (2012). Determinants of foreign direct investment in BRICS economies: analysis of economic, institutional and political factor. Procedia-Social and Behavioral Science, 37, $5-14$. https://doi.org/10.1016/j.sbspro.2012. 03.270.

Jian, C., \& Kamara, Y. A. (2017). An empirical Study on factors influencing foreign direct investment inflows in Sierra Leone. International Journal of Economics, Commerce and Management, 5(1), 514 -520.

Kayode, O., Babatunde, O. A., \& Abiodun, F. (2013). An empirical analysis of transport infrastructure investment and economic growth in Nigeria. Social Sciences, 2(6) 179-188.

Kodongo, O., \& Ojah, K. (2016). Does infrastructure really explain economic growth in Sub-Saharan Africa? Review of Development Finance, 6(2), 105-125.

Lall, S. (1997). Selective policies for export promotion: lessons from the Asian tigers. Helsinki, Finland: UNU World Institute for Development Economic Research.

McCune, D., \& Arihant, J. (2003). Investments for peace in Kashmir. Ethics of Development in a Global Environment. Retrieved December 20, 2019, from https://web.stanford.edu/class/e297a/Investments \%20for\%20P eace $\% 20$ in $\% 20$ Kashmir.pdf.

Mughal, M. M., \& Akram, M. and (2011). Does market size affect FDI? the case of Pakistan. Interdisciplinary Journal of Contemporary Research in Business, 2(9), 237-247.

Mohamed Mustafa, A. M. (2019). Contribution of tourism and foreign direct investment to gross domestic product: econometric analysis in the case of Sri Langka. Journal of Asian Finance, Economics and Business, 6(4), 109-114. https://doi.org/10.13106/jafeb.2019.vol6.no4.109

Nantharath, P., \& Kang, E. (2019). The effects of foreign direct investment and economic absorptive capabilities on the economic growth of Lao People's Democratic Republic. Journal of Asian Finance, Economics and Business, 6(3), 151162. https://doi.org/10.13106/jafeb.2019.vol6.no3.151

National Economic and Development Authority. (2014). Philippine development plan 2011-2016 (midterm update). Pasig City, Philippines: National Economic and Development Authority.

National Tax Research Center. 2015. Review of foreign direct investment flows and tax incentives in the Philippines and in the ASEAN region. NTRC Tax Research Journal, 27(4), 5-20.

Nelson, P. (2012). An analysis of the impact of foreign direct investment on the Indian economy. International Journal of Latest Research in Science and Technology, 1(2), 10-24.

Philippine Statistics Authority. (2016).Philippine Statistical Yearbook. Quezon City, Philippines: Philippine Statistics Authority.

Pelinescu, E. (2014). The impact of human capital on economic growth. Procedia Economics and Finance, 22(2015), 184-190.

Romer, P. (1990). Endogenous technological change. Journal of Political Economy, 98(5), S71-S102.

Rye, T. (2017). Transport and economic growth. Paper presented at the SCOTS Annual Conference, Scotland, Edinburgh Napier University, Transport Research Institutte. 
Sanchez-Robles, B. (1998).Infrastructure investment and growth: some empirical evidence, contemporary economic policy. Contemporary Economic Policy, 16(1), 98-108.
Woldemeskel, S. M. (2008). Determinants of foreign direct investment in Ethiopia (Master thesis). Maastricht, Netherland: Maastricht University. 